2000 - 13, septembre

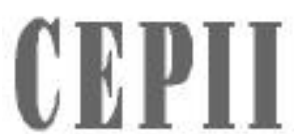

cextan

D'RTUEA FROATECTIVE

Ex D'roronmations

INTEN W ATHONALE

International Trade and Firms' Heterogeneity Under Monopolistic Competition

Sébastien J ean 

International Trade and Firms' Heterogeneity Under Monopolistic Competition

Sébastien J ean

$N^{\circ} 2000-13$, septembre 



\section{TABLE OF CONTENTS}

ABSTRACT T..................................................................................................................................................

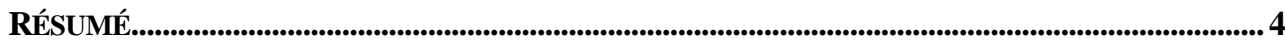

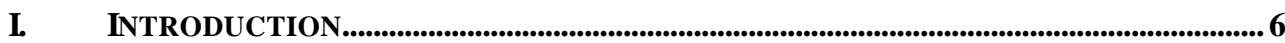

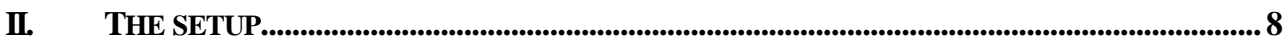

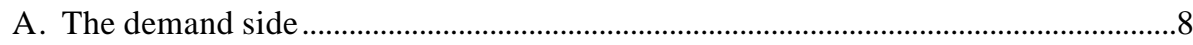

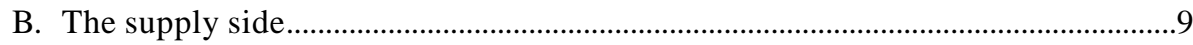

C. Equilibrium for a given population of firms .............................................................11

D. Firms behaviour: entry, exit, and export status...........................................................12

E. Steady-state equilibrium market structure ...................................................................13

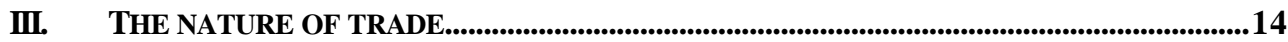

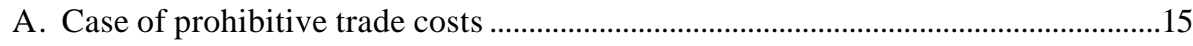

B. Case of "semi-prohibitive" trade costs ........................................................................15

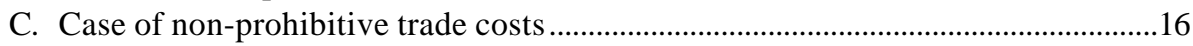

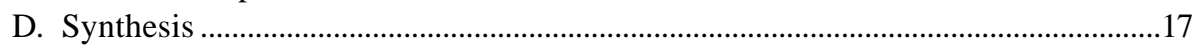

IV. IMPLICATIONS FOR MARKET STRUCTURE AND PRODUCTIVE EFFICIENCY.............18

A. Implications in a context of purely inter-industry trade ..............................................18

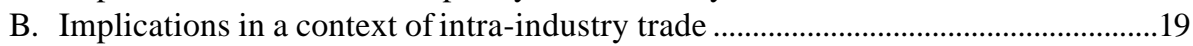

C. The impact of international trade: defensive logic vs. offensive logic ......................20

V. CONCLUSION

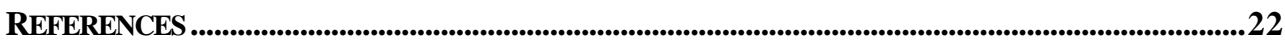

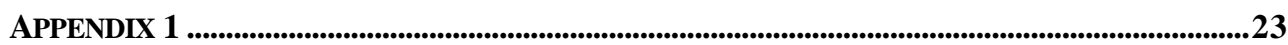

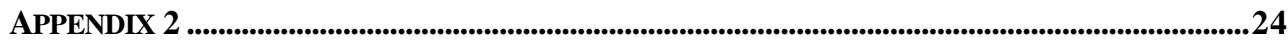

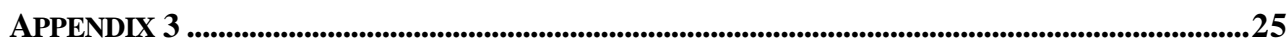

LIST OF WORKING PAPERS RELEASED BY CEPII.....................................................................................28 


\begin{abstract}
This paper aims at shedding some light on the interactions between international trade and firms' heterogeneity, by proposing a tractable model consistent with the stylised facts unveiled by the recent empirical literature. The model describes, in a general equilibrium framework, two economies producing and trading two goods, one homogeneous and the other differentiated. In the differentiated-good sector, firms are heterogeneous by their marginal cost, in a context of monopolistic competition with free-entry and exit. They incur a fixed production cost, but also a fixed cost if they choose to export. We pay special attention to the way firms' heterogeneity influences the nature of trade and, reciprocally, to the impact of trade on the population of firms, and to its consequences in terms of industrywide efficiency. In particular, we show that trade in differentiated goods increases industrywide efficiency, through two different logics: one defensive, import-driven; the other offensive, export-driven. Furthermore, as soon as international efficiency differences and trade cost are sufficiently low, the offensive logic is dominant in shaping the impact of trade.
\end{abstract}

JEL Classification: F12, L11.

Keywords: International trade; Firms' heterogeneity; Product differentiation; Monopolistic competition; Productive efficiency. 


\section{RESUME}

Les théories usuelles du commerce international reposent sur l'hypothèse simplificatrice d'homogénéité des firmes. Or, plusieurs études empiriques récentes ont montré que les firmes diffèrent fortement par leurs performances, et que cette hétérogénéité est importante pour comprendre les effets du commerce extérieur. Il semble par exemple que l'on ait nettement surestimé les gains potentiels liés aux économies d'échelle internes aux firmes, à la suite d'une libéralisation des échanges : d'une part, la sensibilité du coût unitaire au niveau de production semble avoir été surévaluée, d'autre part, l'augmentation de la taille moyenne des firmes profite en pratique essentiellement aux plus grosses firmes, qui ont souvent déjà atteint la taille minimale optimale et ne peuvent donc guère bénéficier d'économies d'échelle supplémentaires. Par ailleurs, la croissance de l'emploi dans les firmes exportatrices pourrait avoir joué un rôle important dans l'augmentation de la demande relative de travail qualifié.

Plus généralement, la littérature empirique récente a permis de dégager un certain nombre de résultats robustes, que l'on peut résumer comme suit :

i. Seule une fraction des firmes exporte, et les firmes exportatrices sont significativement différentes des autres. Elles sont généralement minoritaires, et elles sont de plus grande taille et plus productives que les autres. De surcroît, elles sont plus atypiques en termes de productivité, et moins en termes de taille, dans les secteurs où l'économie pâtit d'un désavantage comparatif.

ii. Cette spécificité des firmes exportatrices n'apparaît pas comme le résultat d'un quelconque effet d'apprentissage. Le lien de causalité est inverse : les bonnes firmes deviennent exportatrices, et cela influe sur leur niveau de production, mais pas sur leur niveau de productivité.

iii. Le commerce international peut induire des redistributions sensibles de ressources productives entre les firmes, au sein même des secteurs, induisant d'importants effets de réallocation. C'est un aspect important des rationalisations induites par la libéralisation commerciale dans les pays en développement, mais même aux Etats-Unis, l'intensification des exportations est à l'origine d'importantes réallocations de ressources des firmes les moins productives vers les plus productives.

iv. L'expérience passée à l'exportation est importante dans la détermination du comportement présent d'exportation des firmes, ce qui suggère que l'exportation implique d'importants coûts non recouvrables.

En dépit de ces résultats frappants, la théorie du commerce international n'a pas grand chose à apporter quant à la compréhension des interactions entre l'hétérogénéité des firmes et les échanges extérieurs. Le but de ce document de travail est de proposer un modèle manipulable susceptible d'éclairer ce point.

Le modèle décrit, dans un cadre d'équilibre général, deux économies produisant et échangeant deux biens, l'un homogène et l'autre différencié. Dans le secteur produisant des biens différenciés, les firmes sont hétérogènes par leur coût marginal, dans un cadre de 
concurrence monopolistique avec libre entrée-sortie ; il existe un coût fixe de production, et les firmes qui exportent doivent également acquitter un coût fixe d'exportation. L'étude accorde une attention particulière à la façon dont l'hétérogénéité des firmes influe sur la nature des échanges et, réciproquement, à l'impact du commerce international sur la population de firmes. On montre en particulier que le commerce de biens différenciés accrôit l'efficacité productive moyenne dans le secteur, au travers de deux types de logiques. L'une est défensive, guidée par les importations : c'est l'élimination des firmes les moins efficaces, induite par la concurrence des importateurs. L'autre est offensive, guidée par les exportations : la perspective de profits supplémentaires grâce à l'exportation attire de nouveaux producteurs, dont l'arrivée attise la concurrence. Dès lors que les différences internationales d'efficacité productive sont suffisamment réduites et les coûts d'échanges suffisamment faibles, cette logique offensive est dominante dans la détermination de l'impact du commerce international.

Classification JEL : F12, L11.

Mots clés : Commerce international ; hétérogénéité des firmes ; différenciation des produits ; concurrence monopolistique; efficacité productive. 


\title{
INTERNATIONAL TrAdE AND FIRMS' HETEROGENEITY UNDER MONOPOLISTIC COMPETITION
}

\author{
Sébastien Jean ${ }^{1}$
}

\section{INTRODUCTION}

The core theories of international trade are based upon the hypothesis of homogenous firms. This is a natural simplifying assumption, but it is strongly questionable, when only a fifth of the firms do actually export anything, as it was the case in the United States in 1992 (Bernard, Eaton, Jensen and Kortum, 2000, p. 4). This may be misleading, also: Tybout and Westbrook (1995) show that, as a result of trade liberalisation in Mexico, the scale efficiency gains were minor, while market-share effects were generally important, as production shifted toward the more efficient plants. They suggest that the gains associated with increasing internal returns to scale have probably been largely overdone, while the effects of reshuffling of output shares among firms have been underestimated. Heterogeneity among firms may also be important in order to understand the link between international trade and labour skill: Bernard and Jensen (1997a) shows that "increases in employment at exporting plants contribute heavily to the observed increase in relative demand for skilled labor in manufacturing" (p. 3).

As a matter of fact, a growing empirical evidence emphasises and documents the importance of firms' heterogeneity ${ }^{2}$ as a determinant both of trade and of its consequences. Several robust results emerge from the recent literature, which hold for various countries:

i. Only a fraction of firms export anything, and exporters are significantly different from nonexporters. They are generally in the minority, and they are larger and more productive than nonexporters (see in particular Bernard et al., 2000). Furthermore, exporters tend to be more atypical in terms of productivity, and less in terms of size, in industries where the economy has a comparative disadvantage (Abd-El-Rahman, 1991).

\footnotetext{
${ }^{1}$ Economist, CEPII (e-mail: s.jean@cepii.fr). I am grateful to Antoine Bouët, Lionel Fontagné, Michel Fouquin, Jean-Louis Guérin, and Catia Montagna for helpful comments and suggestions on an earlier version of this paper. I also benefited from comments by the participants at the ERWIT, CEPR-EPRU, Copenhagen, where this paper was presented. Usual disclaimers apply.

${ }^{2}$ Many of these results actually deal with heterogeneity among plants, because individual data is available for plants in some countries, and for firms in some others. We will use the term "firm" in the following, and for the sake of simplicity we will not deal with the problem of multi-plant firms. However, Clerides, Lach and Tybout (1998, p. 914) reports that, in semi-industrialised countries where the calculation is possible, 95 percent of plants are owned by single-plant firms.
} 
ii. This specificity of exporters does not seem to be the result of any learning-by-exporting. The causality is the other way round: good firms become exporters, and this has a positive influence on their output, but not on their productivity (Clerides, Lach and Tybout, 1998; Bernard and Jensen, 1999a and b).

iii. International trade can induce a significant reshuffling of output-shares among firms, within a given industry, thus giving rise to important share effects. This appears as an important aspect of the rationalising effect induced by trade liberalisation in developing countries (Tybout and Westbrook, 1995; Roberts and Tybout, 1997; Clerides et al., 1998), but even in the United States, exporting is associated with an important reallocation of resources from less efficient to more efficient firms (Bernard and Jensen, 1999b).

iv. Previous export experience is important in setting the export-status of firms, suggesting that there is a significant fixed cost of exporting, in developing countries (Roberts and Tybout, 1997; Clerides et al., 1998), but also in industrialised countries (Bernard and Jensen, 1997b; Bernard and Wagner, 1998).

From a theoretical point of view, however, few studies take into account the heterogeneity of firms as a determinant of international trade. In an informal way, Abd-El-Rahman (1991) proposes hypotheses about the role of firm-specific advantages, depending on the comparative advantage of the country in the corresponding industry. He argues that the diversity in firms' performances explains the existence of minor trade flows, which direction is opposed to that predicted by comparative advantages. The assessment of trade policy leads several authors to consider specifically the heterogeneity of unit costs among firms (a recent example, among many others, is van Long and Soubeyran, 1997). But these studies are limited to the case of homogeneous goods, and they do not provide any explicit description of the selection of firms.

This paper aims at shedding some light on the interactions between international trade and firms' heterogeneity, by proposing a tractable model consistent with the stylised facts mentioned above. While doing this, we will pay special attention to the way firms' heterogeneity influences the nature of trade and, reciprocally, to the impact of international trade on the population of firms, and to its consequences in terms of industry-wide efficiency.

These objectives require building a trade model in which firms are heterogeneous, and describing explicitly the selection process of firms by market entry-exit. In order to do this, we build on the autarkic partial equilibrium model proposed by Montagna (1995) ${ }^{3}$. It describes a market where firms producing horizontally differentiated products are in monopolistic competition. The marginal production cost, randomly drawn, is firm-specific. Given the existence of a fixed production cost, only firms with a sufficiently low marginal cost are able to survive. Firms can freely enter or quit the market, given that potential

\footnotetext{
${ }^{3}$ Montagna (2000) also proposed an extension of this model to a general equilibrium framework, to study the effect of economic integration. But this approach is really different, as it focuses on the study of the integrated economy. It does not deal with nature of trade, and it is not coherent with the stylised facts described above.
} 
entrants do not know their marginal production cost until they begin to produce. The dynamic firm-selection process through free entry-exit leads to a unique steady-state equilibrium, which can be characterised analytically.

The model proposed here completes this description of the determinants of firms heterogeneity by assuming that incumbent firms (once they know their marginal cost) can freely choose to export or not, given the existence of a fixed cost of exporting and of an $a d$ valorem tariff barrier. This description of firms' behaviour is embedded in a general equilibrium framework, with two economies producing and trading two goods, one homogeneous and the other differentiated.

Depending on the values of the parameters, and in particular on the magnitude of trade costs, of country-wide efficiency differences, and of firms heterogeneity, we describe how different trade patterns may emerge. In all cases, we find that trade openness increases the average productive efficiency in the differentiated-good sector, but we show that the impact of trade stems from two different logics: one defensive, import-driven, the other offensive, export-driven.

The paper is organised as follows. The setup of the model is presented in section II. Section III discusses the nature of trade, depending on the parameters. In section IV, the implications for the population of firms and for industry-wide productive efficiency are studied. Section V concludes.

\section{THE SETUP}

Consider two countries $A$ and $B$, producing and trading an homogeneous good $\mathrm{H}$ and a differentiated good $\mathrm{D}$, with one production factor, labour, whose endowment is assumed to be exogenously given for each country.

\section{A. The demand side}

A Cobb-Douglas utility function characterises consumer preferences between the two goods:

$$
\left.U_{c}=H_{c}^{1-\alpha} D_{c}^{\alpha}, \quad \alpha \in\right] 0 ; 1[
$$

Where the index $c=\mathrm{A}$ or B refers to the country, $U$ is the utility, $H$ is the consumption of homogeneous good, $D$ the composite index for consumption of the differentiated good:

$$
D_{c}=\left(\sum_{i \in I_{c} \bigcup^{I}, \exp } D_{i c}^{(\sigma-1) / \sigma}\right)^{\sigma /(\sigma-1)}
$$

Where the index $\bar{c}$ denotes the complement of $c$ in $\{A, B\}$ (the "other country"), and the index $i$ refers to the variety produced by firm $i . D_{\text {ic }}$ is the consumption of variety $i$ in country $c$, the set $I_{\mathrm{c}}$ groups the indices of the varieties produced in country $c, I_{\mathrm{c} \text { exp }}$ groups the 
indices of the varieties produced in country $c$ and exported to country $\bar{c}$. Imported varieties are thus treated in the same way as domestic ones: for an equal price, they will be addressed the same demand. $\sigma$ is the elasticity of substitution between varieties $(\sigma>1)$.

The consumer seeks to maximise his utility under his budget constraint. Assuming trade to be balanced, this constraint is:

$$
M_{c}=H_{c}+P_{c} D_{c}=H_{c}+\sum_{i \in I_{c} \cup I_{\bar{c}, \exp }} P_{i c} D_{i c}
$$

Where the price of the homogeneous good is chosen as the numeraire (as this good is homogeneous, and as it is assumed to be tradable without cost, its price is the same in both countries), $M_{\mathrm{c}}$ is the income of country $c, P_{\text {ic }}$ is the price paid for one unity of variety $i$ in country $c, D_{\mathrm{c}}$ is the composite index of consumption of the differentiated good in country $c$, and the price index $P_{\mathrm{c}}$ for the bundle of differentiated good in country $c$ is defined by:

$$
P_{c}=\left(\sum_{i \in I_{c} \cup I_{\bar{c}, \exp }} P_{i c}^{1-\sigma}\right)^{1 /(1-\sigma)}
$$

As a result, the demand for the two types of goods in country $c$ is:

$$
H_{c}=(1-\alpha) M_{c}, D_{c}=\alpha M_{c} / P_{c}
$$

And the demand addressed, in country $c$, for variety $i$ is:

$$
D_{i c}=\alpha M_{c} P_{c}^{\sigma-1} P_{i c}^{-\sigma}
$$

That is, the demand addressed to a given variety depends on the number of supplied varieties, on the consumption price index of the homogeneous good in the country, and of course on its own price.

\section{B. The supply side}

The production in the homogeneous-good sector is supposed to exhibit constant returns to scale, with a productivity equal to one, so that the labour input $L_{\mathrm{c}, \mathrm{H}}$ required to produce $Q_{\mathrm{c}, \mathrm{H}}$ is:

$$
L_{c, H}=Q_{c, H}
$$

As a consequence, as soon as each country has a non-zero production in this good (which we will assume to be the case), the nominal wage in both countries is equal to one $\left(w_{\mathrm{c}}=1\right)$.

For the production of the differentiated good, the cost function of firm $\mathrm{i}$ is: 


$$
C_{i}=\beta_{i} Q_{i}+K
$$

Where $Q_{\mathrm{i}}$ is the output, $\beta_{\mathrm{i}}$ is the (constant) marginal cost of production, and $K$ is the fixed cost (costs correspond to labour inputs, as this is the only production factor). The existence of a fixed production cost induces a natural monopoly in the production of each variety and we will assume, reciprocally, that each firm produces only one variety. There is consequently a one-to-one correspondence between firms and varieties. The fixed cost is assumed to be identical for all firms, and from one country to another. The heterogeneity of firms stems from their marginal cost $\beta_{\mathrm{i}}$, which is firm-specific. The differences in marginal cost can be linked to differences in organisation, in management, in production techniques, in the rate of default, as well as in the quality of workers. ${ }^{4}$

Competition is modelled à la Bertrand, assuming that conjectural variations are null (for every couple of varieties $\left.(i, j), \partial P_{\mathrm{j}} / \partial P_{\mathrm{i}}=0\right)$ and that each firm considers itself as small with respect to the market $\left(\partial P / \partial P_{\mathrm{i}}=0\right)$. For sales in the domestic market, profit maximisation then leads firm i to set its price as follows:

$$
P_{i, c}=\frac{\sigma}{\sigma-1} \beta_{i}, \forall i \in I_{c}
$$

Under these hypotheses of monopolistic competition, the mark-up ratio between the price and the marginal cost is constant and does not depend on the market share of the firm. The heterogeneity of firms marginal costs is therefore reflected proportionally in prices, and defines an asymmetrical equilibrium in terms of market share and profit, the most efficient firms having a higher market share and higher profits.

The firms which do not export thus earn a profit:

$$
\Pi_{i}=\varphi \alpha M_{c} P_{c}^{\sigma-1} \beta_{i}^{1-\sigma}-K, \forall i \in I_{c, n o n-\exp }
$$

Where we have noted $\varphi=(\sigma-1)^{\sigma-1} \sigma^{-\sigma}, \Pi_{\mathrm{i}}$ denotes the profit of firm $i, \mathrm{I}_{\mathrm{c} \text {,non-exp }}$ is the set of country $c$ 's firms which do not export (therefore, $\mathrm{I}_{c}=\mathrm{I}_{c, \exp } \cup \mathrm{I}_{c \text {,non-exp }}$ ).

Exporting firms incur a fixed cost, $K_{\text {exp }}$, which is a consequence of the costs of access to information, of marketing, of management or of technical and commercial adaptation, inherent to exporting. As for the fixed production cost, we will assume that this fixed cost has to be paid at the beginning of each period. ${ }^{5}$ Exporting firms also incur a tariff barrier $a d$ valorem, with a rate $t$. This tariff $t$ introduces a gap between the price effectively received by

\footnotetext{
${ }^{4}$ Although it is not strictly compatible with the setup of the model, differences in quality of the goods produced could also be interpreted as differences in cost per 'standardised' unit.

${ }^{5}$ There are also sunk entry cost to the export market, which are no longer paid afterwards. For the sake of simplicity, we do not take them into account. The fixed cost considered here can also be understood as the uniform flow whose discounted value is equal to the entry cost, plus the cost of maintaining the capacity to export.
} 
the firm and the price paid by the consumer, $\mathrm{P}_{\text {consumer }}$. Profit maximisation leads the exporters to apply the same mark-up ratio as in their domestic market, between their marginal cost and the price they receive. However, the consumer must in addition pay for the tariff. As a consequence, the firm receives the same unit price $P_{\mathrm{i}, \mathrm{c}}$ (defined in (9)) as for its sales in its domestic market, but the unit price paid by the consumer is:

$$
P_{i \bar{c}}^{\text {consumer }}=(1+t) \frac{\sigma}{\sigma-1} \beta_{i}, \forall i \in I_{c, \exp }
$$

The profit of exporting firms is thus:

(12) $\Pi_{i}=\underbrace{\varphi \alpha M_{c} P_{c}^{\sigma-1} \beta_{i}^{1-\sigma}-K}_{\text {profitonthe domestiomarket }\left(\Pi_{i, \text { dom }}\right)}+\underbrace{\varphi \alpha M_{\bar{c}} P_{\bar{c}}{ }^{\sigma-1}(1+t)^{-\sigma} \beta_{i}{ }^{1-\sigma}-K_{\exp }}_{\text {profitonthe foreignmarket }\left(\Pi_{i, \exp }\right)}, \forall i \in I_{c, \exp }$

In this expression, two terms are distinguished, for the sake of clarity: the first one corresponds to the profit on the domestic market, in the sense that it is the profit the firm would earn, would it sell only in its domestic market; exporting involves an additional profit, that we call profit on the foreign market, or export-profit, and which corresponds to the second term.

The tariff revenue is assumed to be redistributed through a lump-sum transfer. For each country, the income is then

$$
M_{c}=\bar{L}_{c}+\sum_{i \in I_{c}} \Pi_{i}+\frac{t}{1+t} \sum_{i \in I_{\bar{c}, \exp }} P_{i, c} D_{i, c}
$$

Where $\bar{L}_{c}$ is the exogenous endowment of country $c$ in labour.

\section{Equilibrium for a given population of firms}

For each variety of the differentiated good,

$$
Q_{i}=D_{i, c}+D_{i, \bar{c}}, \forall i \in I_{c}
$$

Where the second term is zero for the non-exported varieties. The equilibrium on the labour market requires

$$
\bar{L}_{c}=L_{c, H}+N_{c} K+N_{c, \exp } K_{\exp }+\sum_{i \in I_{c}} \beta_{i} Q_{i}
$$

For a given population of firms, equations (2) to (15) enable the general equilibrium of the two economies to be characterised (the equilibrium in the homogeneous-good market does not need to be written explicitly, because of the Walras' law). Note in particular that for given parameters and factor endowments, trade flows in the differentiated-good sector depend on the number and the characteristics (level of marginal cost and export status) of 
firms producing the differentiated good in each country. These trade flows, if any, can be either two-way or one way (if one country has no exporting firm). Trade in homogeneous good, in contrast, is always one-way, and compensate exactly the net balance of trade in the differentiated-good sector.

\section{Firms behaviour: entry, exit, and export status}

Let us turn to the process of entry and exit of firms in the differentiated-good sector. As in Montagna (1995), both entry and exit are free, but potential entrants do not know their marginal cost: they only know the distribution from which it will be drawn if they decide to produce.

Concretely, the firm-specific marginal cost is randomly drawn from a continuous uniform distribution defined over a country-specific interval, $\left.\mathbb{\beta}_{\mathrm{c} \text {,inf }} ; \beta_{\mathrm{c}, \text { sup }}\right]=\left[\phi_{\mathrm{c}}(1-\delta) ; \phi_{\mathrm{c}}(1+\delta)\right]$ (with $\phi_{c}>0$ and $\left.0 \leq \delta<1\right)$. The larger this interval is, the more heterogeneous the firms are likely to be within the industry. When the interval reduces to a single point $\delta=0$ ), firms are homogeneous. The two country-specific intervals are thus assumed to be homothetic, that is: $\beta_{\mathrm{A} \text {,sup }} / \beta_{\mathrm{B} \text {,sup }}=\beta_{\mathrm{A} \text {,inf }} / \beta_{\mathrm{B} \text {,inf }}=\phi_{\mathrm{A}} / \phi_{\mathrm{B}}$. The standard deviation compared to the average is then a priori identical for both distributions. ${ }^{6}$ This means that the ex ante degree of uncertainty of the production process is the same in both countries. Thereby, we assume that the uncertainty in marginal cost is linked to the disparity in individual performances, while international differences in the expected marginal cost are related to country-wide conditions. $\phi_{\mathrm{A}}<\phi_{\mathrm{B}}$ would for instance mean that these country-wide conditions are more favourable in country $A$.

If a firm chooses to enter the market, i.e. to produce, it incurs a fixed production cost. It will then (and only then) know the level of its marginal cost. Each firm can also freely choose whether to export or not, but the decision to export is taken once the marginal cost is known.

Each firm have to pay the fixed production cost at the beginning of each production period. This periodical repetition is justified by the depreciation or the technical evolution of material investments (or by the fact that, when the investments are reversible, firms only pay for their use-cost), and by the necessary adaptation of immaterial investments (like training, $\mathrm{R} \& \mathrm{D}$, marketing, etc.) to market evolutions. The fixed export cost is also incured at each period, as a result of the necessity to maintain the capacity to export.?

Each incumbent is free to quit the market at each period: it will do so if its profit is negative. Each firm can also change its export status at each period. The decision with respect to this will be taken on the basis of the sign of the export profit for the current period.

\footnotetext{
${ }^{6}$ This is not the case when the second interval is obtained from the first one by translation, as assumed by Montagna (2000).

${ }^{7}$ This hypothesis is supported by the finding of Roberts and Tybout (1997, p. 559), that the benefit of export experience depreciates very quickly.
} 
The behaviour of firms can then be summarised as follows. Potential entrants are assumed to be risk-neutral and to form static expectations about their future profits, taking as given the number of firms in each market. As a consequence, some will decide to enter the market if and only if the expected profit on their domestic market is non-negative. Among those which entered the market, only firms whose marginal cost is sufficiently low in order to enable the export receipts to compensate the associated fixed cost, will export. At each period, only those which marginal cost is sufficiently low to be able to make non-negative profits, will survive.

\section{E. Steady-state equilibrium market structure}

We assume in addition that, if a steady-state equilibrium is reached, no firm can export without making non-negative profits in the domestic market, i.e. that a firm making negative profits in its domestic market cannot export profitably. This hypothesis is made for the sake of coherence with the hypothesis of monopolistic competition. ${ }^{8}$

The population and export status of firms will reach an equilibrium when three conditions are met for each country:

- there is no exit, because all incumbents make non-negative profits on their domestic market:

$$
\forall i \in I_{c}, \beta_{i} \leq \beta_{c}^{*} / \Pi_{c}\left(\beta_{c}^{*}\right)=\varphi \alpha M_{c} P_{c}^{\sigma-1} \beta_{c}^{* 1-\sigma}-K=0
$$

- there is no shift in export-status, as each exporter makes non-negative export-profit, and each nonexporter could not earn positive profit by exporting:

$$
\begin{aligned}
& \forall i \in I_{c, \exp }, \forall j \in I_{c, n o n-\exp }, \beta_{i} \leq \beta_{c, \exp }^{*} \text { and } \beta_{j} \geq \beta_{c, \exp }^{*} / \\
& \quad \Pi_{c, \exp }\left(\beta_{c, \exp }^{*}\right)=\varphi \alpha M_{\bar{c}} P_{\bar{c}}^{\sigma-1}(1+t)^{-\sigma} \beta_{c, \exp }^{*}{ }^{1-\sigma}-K_{\exp }=0
\end{aligned}
$$

- there is no more entry in the markets, because the expected profits of potential entrants is non-positive:

\footnotetext{
${ }^{8}$ When trade costs are very weak compared to the fixed production cost, exporting can be profitable, even for a firm that cannot sell profitably in its domestic market separately. In this case, all firms export. This is not unrealistic, if we think for instance about the aeronautics, automotive, pharmaceutical or computer industries. These industries have indeed the specificity of having very high fixed costs which, in the context of liberalised trade and low transportation cost, can only be made profitable through exporting. However, the strategic interaction of firms is crucial in this type of industries, that are generally highly concentrated. The model presented here, with monopolistic competition, therefore does not seem very adequate in this case.
} 


$$
\begin{aligned}
& E\left(\Pi_{c}\right)=\int_{\beta_{c, \text { inf }}}^{\beta_{c, \text { sup }}}\left[\varphi \alpha M_{c} P_{c}^{\sigma-1} \beta^{1-\sigma}-K\right] f_{c}(\beta) d \beta \\
& \quad+\int_{\beta_{c, \text { inf }}}^{\beta_{c, \exp }^{*}}\left[\varphi \alpha M_{\bar{c}} P_{\bar{c}}^{\sigma-1}(1+t)^{-\sigma} \beta^{1-\sigma}-K_{\exp }\right] f_{c}(\beta) d \beta \leq 0
\end{aligned}
$$

where $f_{\mathrm{c}}(\beta)=1 /\left(\beta_{\mathrm{c}, \text { sup }}-\beta_{\mathrm{c} \text {,inf }}\right)=1 /\left(2 \delta \phi_{\mathrm{c}}\right)$ is the distribution density function of random variable $\beta$ in country $c . \Pi_{c, \text { exp }}$ denotes export-profit, $\beta^{*}{ }_{c}$ is the maximum marginal cost required for a firm to survive in country $c, \beta_{\mathrm{c} \text { exp }}^{*}$ is the maximum marginal cost required for a country $c$ 's firm to export (if exporting is not profitable even for a firm with the lowest marginal cost possible in country $c, \beta_{\mathrm{c}, \text { inf }}$, then we will set $\beta_{\mathrm{c}, \text { exp }}^{*}=\beta_{\mathrm{c}, \text { inf }}$ ). In equation (18), the first integral corresponds to the expected domestic profit, which is calculated over all the possible values of $\beta$. The second integral corresponds to the export profit. As the choice of the export status is made only once the marginal cost is known, this second integral only takes into account the cases where the marginal cost is sufficiently low to enable the export profit of the firm to be positive: its superior bound is not $\beta_{\mathrm{c}, \text { inf }}$, but $\beta_{\mathrm{c} \text { exp }}^{*}$.

Given our hypothesis that a firm making negative profits in its domestic market cannot export profitably, these three equations, together with equations (2) to (15), define the free entry-exit steady-state equilibrium of the two economies. These equilibrium conditions for entry and exit are stable. If a firm does not meet condition (16) or (17), then it will either exit or change its export status. If equation (18) is not true, this means that expected profit for potential entrants is positive; this would induce some firms to enter the market, thus lowering its profitability (because they lower the price index of the industry, as soon as they are able to stay on the market), and therefore lowering the expected profit for potential entrants, until equation (18) is met.

Note that, in spite of the free entry-exit, profits are not necessarily zero in the steady-state, as potential entrants face uncerntainty about the value of their marginal costs (see Montagna, 1995, for details).

As soon as at least one country $c$ 's firm export in the steady-state, then condition (17), reflecting the stability of firms' export status, shows that exporters have a lower marginal production cost than nonexporters. Consistently with the stylised facts, exporters are bigger and more efficient than nonexporters in this model. In addition, they are more profitable. ${ }^{9}$

\section{THE NATURE OF TRADE}

Depending on the parameters and on the population of incumbent firms, the set-up exposed above can lead to different kind of trade flows.

\footnotetext{
${ }^{9}$ As a consequence, differences in productivities among firms are not wholly counterbalanced by differences in wages. This is important, as emphasised by Bernard et al. (2000, p. 2): as long as differences in productivity are completely reflected in prices, apparent productivity as measured through value added per worker is the same across firms, whatever their differences in productive efficiency. In the present case, exporters' productivity is higher, even when it is measured through value added per worker.
} 


\section{A. Case of prohibitive trade costs}

Trade costs are prohibitive when, in both countries, no firm can export. More precisely,

$$
\Pi_{c, \exp }\left(\beta_{c, \text { inf }}\right) \leq 0 \Rightarrow I_{c, \exp }=\varnothing
$$

In this case, no trade takes place, and both countries are in autarky. The market structure is then determined by equilibrium conditions (16) and (18). As shown by Montagna (1995), the maximum marginal cost $\beta_{\mathrm{c}}$, aut required to be profitable is then:

$$
\beta_{c, \text { aut }}=\left(\int_{\beta_{c, \text { inf }}}^{\beta_{c \text { sup }}} \beta^{1-\sigma} f_{c}(\beta) d \beta\right)^{1 /(1-\sigma)}=\phi_{c}\left(\int_{1-\delta}^{1+\delta} \frac{\beta^{1-\sigma}}{2 \delta} d \beta\right)^{1 /(1-\sigma)}=\phi_{c} \beta_{\text {aut }}
$$

Where we have noted, for the sake of simplicity, $\beta_{a u t}=\left(\int_{1-\delta}^{1+\delta} \frac{\beta^{1-\sigma}}{2 \delta} d \beta\right)^{1 /(1-\sigma)}$. Note that

Baut only depends on the parameters $\delta$ and $\sigma$, and can thus be considered as a parameter here. As $\Pi\left(\beta_{\mathrm{c}, \text { aut }}\right)=0$, proposition (19) can be re-written:

$$
\frac{(1+t)^{\sigma} K_{\mathrm{exp}}}{K} \geq\left(\frac{\phi_{\bar{c}}}{\phi_{c}} \frac{\beta_{a u t}}{1-\delta}\right)^{\sigma-1} \Rightarrow I_{c, \exp }=\varnothing
$$

The left hand side term of the inequality measures the importance of trade costs compared to the fixed production cost. Indirectly, it makes it possible to compare the profitability of sales in the foreign market with respect to the profitability of sales in the domestic market. If this term exceeds the right hand side's one, it means that export costs are so high that even the most efficient firm in a country cannot export profitably. Trade costs are prohibitive, and the two countries do not trade at all.

\section{B. Case of "semi-prohibitive" trade costs}

The level for which trade costs turn to be prohibitive depends on the relative a priori technological levels of the two countries. Let us assume that country-wide production conditions for the differentiated good are more favourable in $A$ than in $B\left(\phi_{\mathrm{A}}<\phi_{\mathrm{B}}\right)$, and suppose that

$$
\left(\frac{\phi_{B}}{\phi_{A}} \frac{\beta_{a u t}}{1-\delta}\right)^{\sigma-1}>\frac{(1+t)^{\sigma} K_{\exp }}{K} \geq\left(\frac{\phi_{A}}{\phi_{B}} \frac{\beta_{a u t}}{1-\delta}\right)^{\sigma-1}
$$

In this case, trade costs are too high (compared to the fixed production cost) to make exports profitable for any firm in country $B$. In contrast, at least with the autarkic market conditions in $B$, exporting is profitable for a firm which marginal cost is equal to the minimum bound of the distribution in country $A$. As a consequence, if at least one firm in country $A$ have a marginal cost sufficiently close to the lower bound of the distribution (which we can 
assume to be the case, if the number of firms is sufficiently large), then it will export: a purely inter-industry trade takes place, where country $A$ exports differentiated goods to country $B$, and imports homogeneous goods from there (trade between both countries remains balanced, by assumption).

\section{Case of non-prohibitive trade costs}

When trade costs are sufficiently low, they are not prohibitive, even for the economy where country-wide production conditions for the differentiated good are less favourable (let us still assume that this country is $B: \phi_{\mathrm{A}} \leq \phi_{\mathrm{B}}$ ). However, we assumed that exporting is not profitable for a firm that cannot earn non-negative profits on its domestic market alone. This hypothesis implies that, necessarily,

$$
\frac{(1+t)^{\sigma} K_{\exp }}{K} \geq 1
$$

This simply means that when this inequality ${ }^{10}$ is not met, the model is not well-suited to describe the situation, because the differentiated-good industry has an oligopolistic structure.

Given this inferior bound on trade costs, it can be shown that there exists $\left.\varphi_{0} \in\right] \frac{1-\delta}{\beta_{\text {aut }}} ; 1[$ such that:

$$
\begin{aligned}
& \left\{\exists T C\left(\phi_{A} / \phi_{B}\right) \in\right] ;\left(\frac{\beta_{a u t}}{1-\delta} \frac{\phi_{A}}{\phi_{B}}\right)^{\sigma-1}\left[\left\{\frac{(1+t)^{\sigma} K_{\exp }}{K}<T C\left(\phi_{A} / \phi_{B}\right) \Rightarrow\left\{\begin{array}{l}
\beta_{A, \exp }>\beta_{A, \text { inf }} \\
\beta_{B, \exp }>\beta_{B, \text { inf }}
\end{array}\right\}\right\}\right. \\
& \Leftrightarrow \frac{\phi_{A}}{\phi_{B}} \in\left[\varphi_{0} ; 1\right]
\end{aligned}
$$

Proof: see Appendix 1.

This means that if the ratio, between the two countries, of expected productive efficiencies exceeds a given level $\left(\varphi_{0}\right)$, then sufficiently low trade costs leads to a complete

\footnotetext{
${ }^{10}$ The corresponding level for trade cost, compared to the fixed production cost, may seem very high. This is due to the fact that the demand addressed to foreign variety is assumed to be the same, for a same price, than the demand addressed to domestically-produced varieties. In practice, the demand is usually superior for the domestic variety, for the same price; in these conditions, the inferior limit for ratio (23) is inferior to unity.
} 
specialisation: ${ }^{11}$ the international efficiency difference is so high, in this case, that an increased competition from country $A$ 's exporters induces the cessation of country's $B$ production in the differentiated-good sector.

In contrast, if the ratio of expected productive efficiencies does not exceed $\varphi_{0}$, then sufficiently low trade costs enables a two-way trade to take place in the differentiated goods sector. This trade needs not be balanced by itself, as trade in the homogeneous sector then just balances the net flow in the differentiated-good sector.

\section{Synthesis}

The nature of trade can finally be summarised through Figure 1, where the size of the various areas depend on firms heterogeneity. The case of prohibitive trade costs corresponds to area (a), where no trade occurs. For what we called above "semi-prohibitive" trade costs (area (b)), trade is purely inter-industry: the a priori most efficient country for the production of the differentiated-good product exports this good, and it imports only homogeneous goods. Now when trade costs are inferior to a given threshold (dependant on the degree of firms heterogeneity): if the difference between country-wide production cost levels in the differentiated good is high, then trade remains purely interindustry, but there is complete specialisation, as the less efficient country has no more production in the differentiated-good sector; if country-wide production cost levels in the differentiated good are sufficiently similar, then two-way trade in the differentiated-good may occur, together with a one-way trade flow in the homogeneous good product.

\footnotetext{
${ }^{11}$ We assume that the share of the differentiated good in consumption is sufficiently low, so that the most efficient country has enough labour to produce sufficiently in order to satisfy the whole consumption in this good.
} 
Figure 1: The nature of trade

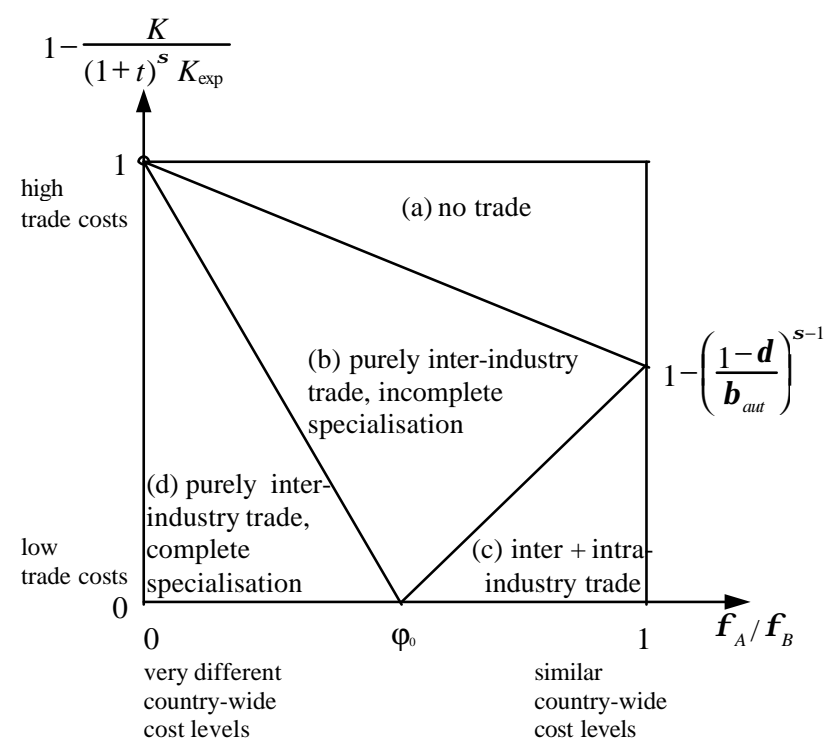

The nature of the influence of the degree of homogeneity on the shape of these areas can be somewhat precised: it can be shown that, for any given $\sigma>1,\left[\beta_{\text {aut }} /(1-\delta)\right]$ is an increasing function of $\delta$ over the interval [0;1[ (see proof in Appendix 2). This shows that, ceteris paribus, as the degree of homogeneity among firms increases, the surface of area (a) decrease, while the surface of (c) increases. The effect on on (b) is uncertain a priori. While it cannot be proved rigourously, (d) is most likely to be reduced when the degree of heterogeneity increases.

\section{IMPLICATIONS FOR MARKET STRUCTURE AND PRODUCTIVE EFFICIENCY}

We have just emphasised that firms heterogeneity is one of the determinants of trade. Reciprocally, trade has an impact on the nature of the population of firms. In particular, we will focus on the influence induced on average productive efficiency. For the sake of simplicity, we will study separately the case of purely inter-industry trade and the case where intra-industry trade takes place.

\section{A. Implications in a context of purely inter-industry trade}

Let us first assume that trade costs are lowered from a prohibitive level to a "semiprohibitive" level. What are the consequences for the least-efficient country (the one whose a priori expected marginal production cost of the differentiated good is the highest), say country $B$ ? Since they catch part of the demand, imports lower the profitability of the domestic market in this country. The upsurge of imports thus causes the bankruptcy of the least-efficient incumbent firms in country $B$. Moreover, in the absence of export opportunities, the expected profit of a potential entrant is also reduced, and turns out to be strictly negative: no firm enter the market, since the reduction in the number of firms is not 
sufficient to restore a positive expected profit for potential entrants. The least-efficient firms are crowded out, without creating any entry opportunity for new firms. The impact on country $B$ 's average productive efficiency in the differentiated-good sector is obviously positive, but no domestic firm sees its profit increase. Formally, equations (17) and (18) are inactive as equilibrium conditions for country $B$. From the initial firms population, only those which marginal cost is inferior to $\beta_{\mathrm{B}}^{*}$, as defined by (16), survive.

In the exporting country (country $A$ ), in contrast, equations (16) to (18) are all active in setting the steady-state equilibrium market structure. Equation (18) expresses the zeroexpected-profit condition for potential entrants. As in autarky, the expected profit in the domestic market is taken into account. But here, it is summed up with the expected exportprofit. The latter is positive as the export decision is taken only once the firm's marginal cost is known. Under free-trade, potential entrants take into account the additional profit they will realise if they are sufficiently efficient to export profitably. Consequently, they may be prone to enter the market even when the profitability of the domestic market at a given level of efficiency is inferior to its autarkic level, i.e. when the expected profit in this single market is negative: the perspective of new profits through exports attracts new producers, whose entry exacerbates competition.

Formally, using the expression of $\beta_{\mathrm{A}, \mathrm{aut}}$ in (20), the zero-expected-profit condition for potential entrants expressed through equation (18) implies that:

$$
\begin{aligned}
& \Pi\left(\beta_{\text {A,aut }}\right)=\varphi \alpha M_{A} P_{A}{ }^{\sigma-1} \beta_{A, \text { aut }}^{1-\sigma}-K \\
& \quad \leq-\int_{\beta_{A, \text { inf }}}^{\beta_{A, \exp }^{*}}\left[\varphi \alpha M_{B} P_{B}{ }^{\sigma-1}(1+t)^{-\sigma} \beta^{1-\sigma}-K_{\exp }\right] f_{A}(\beta) d \beta<0
\end{aligned}
$$

This means that the profit of a firm with a marginal cost $\beta_{\mathrm{A}, \mathrm{aut}}$ is strictly negative. As a consequence, the maximum marginal cost required to survive in country $A$ (defined by equation (16)) is inferior to the one required in autarky. Or, to put it in other words, the efficiency level required to survive is higher. In addition, the most efficient firms, which benefit from export possibilities, increase their market shares with respect to autarky. Thus, by the conjunction of these two effects, exporting increases the expected average efficiency level in the differentiated-good sector.

As the minimal efficiency level required is higher, the probability of failure for a new entrant is also higher in the free-trade case. On the other hand, the most efficient firms have the opportunity, through exports, to enlarge their markets, and thereby their profits. The market of the exporting country thus becomes more risky, but more profitable for the "winners". There is a low probability of earning a lot. Moreover, the disparities in the sizes and profits of firms increase, since the most efficient (that is the biggest in terms of size and profit) are those which most increased their production and their profits thanks to exports.

\section{B. Implications in a context of intra-industry trade}

When two-way trade in differentiated products takes place, the mechanisms are basically the same: imports lower the profitability of the domestic market, while exports increase the expected profit for potential entrants. The implications are clear-cut for the most efficient 
country: as previously, the perspective of new profits through exports attracts new producers, whose entry exacerbates competition. The zero-expected-profit condition for potential entrants (equation (18)) is then active in setting the equilibrium. As stated before through equation (25), this implies that the marginal cost required to survive is inferior to its autarkic level.

For the least efficient country ( $\operatorname{country} B)$, two cases have to be distinguished:

i. Trade opening does not induce any new entry in the domestic market, because the profit opportunities carried out by exports are not sufficient to balance the negative effect of imports on the expected profit for new entrants. In this context, the mechanisms are similar to those mentioned in the previous section for the country importing differentiated goods and exporting homogeneous goods: the zero-expected-profit condition for potential entrants is not active in setting the equilibrium, and the least-efficient firms have to quit the market. The only difference with the case of purely inter-industry trade is that country $B$ 's most efficient firms can export. This also contributes to increase the average productive efficiency in the differentiated-good sector, as it increases the output of the most efficient firms.

ii. The profit opportunities carried out by exports attract new producers, included in the least efficient country. This is the case as soon as the difference in average efficiency level is sufficiently weak, while trade costs are sufficiently low. In this case, even the least efficient country experiments mechanisms similar to those described in the previous section for the country exporting differentiated goods and importing homogeneous goods: the zeroexpected-profit condition for potential entrants is active in setting the equilibrium, and the entry of new producers induces a new selection among firms. In this context, it can be shown that the probability for a new entrant to survive is superior in the most efficient country, while the probability for a new entrant to be able to export profitably is superior in the most efficient country (see proof in Appendix 3). This is coherent with the empirical result of Abd-El-Rahman (1991), which shows that exporting firms are more atypical, in terms of productivity, in industry with comparative disadvantage (i.e. the differentiated-good sector in the least efficient country) than in those industries enjoying a comparative advantage (the differentiated-good sector in the most efficient country). In the words of Abd-El-Rahman, the specific advantage required for a firm in order to be able to export is more important in an industry suffering a comparative disadvantage.

\section{The impact of international trade: defensive logic vs. offensive logic}

In the above study of the impact of trade on firms and on average productive efficiency in the differentiated-good sector, two different types of mechanisms emerge, corresponding respectively to a defensive logic, and to an offensive logic:

i. The defensive logic is import-driven: it is at work when a country has either no exporting firm in the differentiated-good sector, or when the profit opportunities carried out by exports are not sufficient to balance the negative effect of imports on the expected profit for new entrants. In this case, trade opening does not induce any new entry, and the only firms whose profit may increase are the most efficient ones, if they are able to export profitably. 
International trade does improve the average productive efficiency level in the differentiated-good industry, because of the exit of the least efficient firms, and because of the increased output of the most efficient firms, when they are able to export.

ii. The offensive logic is export-driven: it is at work when the profit opportunities carried out by exports attract new producers, compared to autarky. Their entry then exacerbates competition in the sector, reducing the profitability of the domestic market for incumbent firms. In addition, the probability of failure for potential entrants is increased, compared to autarky. As before, average productive efficiency in the sector is increased as a result both of the exit of the least efficient firms and of the increased output of the most efficient ones. Finally, when trade costs and the international difference in average productive efficiency are sufficiently low, this offensive logic dominates the defensive one: the maximum marginal cost required to survive is proportionally more reduced, compared to autarky, in the most efficient country, that is in the country where the export intensity and the proportion of exporting firms in the differentiated-good sector is the highest.

\section{CONCLUSION}

The model presented here aims at enlightening the interactions between international trade and firms' heterogeneity, in a context of monopolistic competition. Based on the autarkic model proposed by Montagna (1995), the coexistence of firms with different marginal costs is the consequence of the uncertainty faced by potential entrants about the level of their marginal cost. The differences in export status then stem from the existence of a fixed cost of exporting.

This model fits quite well with the stylised facts described in the introduction: it is coherent with the fact that only a fraction of firms export anything, that exporters are larger and more productive than nonexporters, that exporters are more atypical in this last respect when the country suffers from a comparative disadvantage in the sector, and that export-driven crossfirm reallocations ("share effects") significantly increase average productive efficiency. In addition, it suggests that the positive effect of import penetration rate on industry-wide productive efficiency (as described for example by Cortes and Jean, 1997, or by Hine and Wright, 1998) may also partly result of cross-firm reallocations. It also sheds some light on how trade costs, country-wide efficiency differences, and firms heterogeneity interact to determine the nature of trade.

Finally, we showed that the impact of trade stems from two different logics: one defensive, import-driven, the other offensive, export-driven. This result emphasises that trade is not only a threat that eliminates the least efficient firms. The trade-induced increase in competitive pressure may also be the result of the entry of new producers, attracted by the new profit opportunities carried out by exports. Furthermore, as soon as country-wide efficiency differences and trade costs are sufficiently low, this offensive logic dominates the defensive logic in shaping the impact of trade. 


\section{REFERENCES}

Abd-El-Rahman K. S. (1991), "Firms' Competitive and National Comparative Advantages a Joint Determinants of Trade Composition", Weltwirtschaftliches Archiv, Vol. 132, No. 4.

Bernard A.B. and Jensen J.B. (1997a), "Exporters, Skill Upgrading, and the Wage Gap", Journal of International Economics, Vol. 42, pp. 3-31.

Bernard A.B. and Jensen J.B.(1997b), "Why Some Firms Export: Experience, Entry Costs, Spillovers, and Subsidies", Yale mimeo.

Bernard A.B. and Jensen J.B. (1999a), "Exceptional Exporter Performance: Cause, Effect or Both?", Journal of International Economics, Vol. 47, No. 1, pp. 1-26.

Bernard A.B. and Jensen J.B. (1999b), "Exporting and Productivity", Working Paper Series, No. 7135 , NBER.

Bernard A.B., Eaton J., Jensen J.B. and Kortum S. (2000), "Plants and Productivity in International Trade", Working Paper Series, No. 7688, NBER.

Bernard A.B. and Wagner J. (1997), "Export and Success in German Manufacturing", Weltwirtschaftliches Archiv, Vol. 133, No. 1, pp. 134-157.

Clerides S., Lach S. et Tybout J. R. (1996), "Is "learning-by-exporting" important ? Microdynamic evidence from Colombia, Mexico and Morocco", Quarterly Journal of Economics, Vol. 113, No. 3, pp. 903-928.

Cortes O. et Jean S. (1997), "Commerce international, emploi et productivité", Travail et Emploi, No. 70, pp. 61-79.

Hine R. C. et Wright P. (1998), "Trade with Low-Wage economies, Employment and Productivity in UK Manufacturing", The Economic Journal, Vol. 108, No. 450, pp. 15001510.

Long (van) N. and Soubeyran A. (1997), "Cost Heterogeneity, Industry Concentration and Strategic Trade Policies", Journal of International Economics, Vol. 43, pp. 207-220.

Montagna C. (1995), "Monopolistic Competition with Firm-Specific Costs", Oxford Economic Papers, Vol. 47, pp. 318-28.

Montagna C. (2000), "Efficiency Gaps, Love of Variety and International Trade", Economica, forthcoming.

Roberts M. and Tybout J. R. (1997), "The Decision to Export in Colombia: An Empirical Model of Entry with Sunk Costs", American Economic Review, Vol. 87, pp. 545-564.

Tybout J. R. and Westbrook M. D. (1995), "Trade Liberalization and the Dimensions of Efficiency Change in Mexican Manufacturing Industries", Journal of International Economics, Vol. 39, pp. 53-78. 


\section{APPENDIX 1}

Proposition (21) implies that

$$
\text { If } \frac{\phi_{A}}{\phi_{B}} \leq \frac{1-\delta}{\beta_{a u t}}, \text { then } I_{B, \exp }=\varnothing
$$

In other words, if the lowest marginal cost possible in country $B$ is superior to the maximum marginal cost required in $A$ to survive in the autarkic equilibrium, then no firms in country $B$ will be able to export profitably to country $A$, whatever the trade costs. In addition, in this case, no firm can survive in country $B$ when $(1+t)^{\sigma} K_{\text {exp }} / \mathrm{K}=1$ (the maximum marginal cost required to survive in then the same as the maximum marginal cost required to export profitably). By continuity (and given that the profitability in the country $B$ 's market decreases when trade costs decrease), there is a critical value for the ratio $(1+t)^{\sigma} K_{\exp } / K$ of trade cost to the fixed production cost, under which there is no more production of the differentiated good in $B$.

Now, if both countries have the same expected productive efficiency in the sector $\left(\phi_{\mathrm{A}} / \phi_{\mathrm{B}}=1\right)$, then $(1+t)^{\sigma} \mathrm{K}_{\text {exp }} / K<\left(\beta_{\text {aut }} /(1-\delta)\right)^{\sigma-1}$ is a sufficient condition to make sure that two-way trade in differentiated goods is likely to take place (in both countries, the maximum marginal cost required to export is superior to the inferior bound of the random distribution of marginal costs: $\left.\beta_{\mathrm{c}, \exp }>\beta_{\mathrm{c}, \mathrm{inf}}\right)$.

In addition, ceteris paribus, the export-profitability is a decreasing function of $(1+t)^{\sigma} K_{\text {exp }} / K$. By continuity, this makes it possible to establish that there is a value $\varphi_{0}$ such that:

$$
\begin{gathered}
\left\{\exists T C\left(\phi_{A} / \phi_{B}\right)>1 /\left\{\frac{(1+t)^{\sigma} K_{\exp }}{K}<T C\left(\phi_{A} / \phi_{B}\right) \Rightarrow\left\{\begin{array}{l}
\beta_{A, \exp }>\beta_{A, \text { inf }} \\
\beta_{B, \exp }>\beta_{B, \text { inf }}
\end{array}\right\}\right\}\right. \\
\Leftrightarrow \frac{\phi_{A}}{\phi_{B}} \in\left[\varphi_{0} ; 1\right]
\end{gathered}
$$

Given proposition (A.1), necessarily $\varphi_{0}>(1-\delta) / \beta_{\text {aut }}$. In addition, following proposition (21), $(1+t)^{\sigma} K_{\text {exp }} / K=\left(\beta_{\text {aut }} /(1-\delta) \phi_{\mathrm{A}} / \phi_{\mathrm{B}}\right)^{\sigma-1}$ implies that no firm can export profitably in country $B$. As a consequence, necessarily, the upper bound of trade costs compatible with two-way trade, $T C\left(\phi_{\mathrm{A}} / \phi_{\mathrm{B}}\right)$, is inferior to $\left(\beta_{\mathrm{aut}} /(1-\delta) \phi_{\mathrm{A}} / \phi_{\mathrm{B}}\right)^{\sigma-1}$. This is sufficient to prove that proposition (24) is true. 


\section{APPENDIX 2}

Given that $\beta_{\text {aut }}=\left(\int_{1-\delta}^{1+\delta} \frac{\beta^{1-\sigma}}{2 \delta} d \beta\right)^{1 /(1-\sigma)}$, it comes: $\left(\frac{\beta_{\text {aut }}}{1-\delta}\right)^{1-\sigma}=\int_{1-\delta}^{1+\delta} \frac{\left(\frac{\beta}{1-\delta}\right)^{1-\sigma}}{2 \delta} d \beta$

Changing the variable $\beta$ under the integral for $\theta=\beta /(1-\delta)$, we obtain:

$$
\left(\frac{\beta_{a u t}}{1-\delta}\right)^{1-\sigma}=\frac{1-\delta}{2 \delta} \int_{1}^{1+\delta} \frac{1-\delta}{1-\sigma} d \theta
$$

The derivative of this last expression with respect to $\delta$ is:

$$
\begin{aligned}
\frac{\partial}{\partial \delta}\left[\left(\frac{\beta_{\text {aut }}}{1-\delta}\right)^{1-\sigma}\right] & =\frac{1-\delta}{2 \delta}\left(\frac{1+\delta}{1-\delta}\right)^{1-\sigma} \frac{2}{(1-\delta)^{2}}-\frac{1}{4 \delta^{2}} \int_{1}^{1-\delta} \theta^{1-\sigma} d \theta \\
& \leq\left(\frac{1+\delta}{1-\delta}\right)^{-\sigma}\left[1-\frac{1+\delta}{4 \delta^{2}(1-\delta)}\right] \\
& \leq 0, \forall \delta \in[0 ; 1[
\end{aligned}
$$

This proves this announced property : for any given $\left.\sigma>1, \mathbb{\beta}_{\text {aut }} /(1-\delta)\right]$ is an increasing function of $\delta$ over the interval $[0 ; 1[$. 


\section{APPENDIX 3}

This appendix aims at characterising the populations of firms when the zero-expected-profit condition for potential entrants is active in setting the equilibrium for both countries, that is when the offensive logic is at work both in country $A$ and $B$. When this is the case, the steady-state population of firms is characterised through equations (16) to (18). In addition, we will assume that the expected profit for potential entrants is exactly zero, instead of assuming it to be non-positive. As long as the entry of firms is incremental, and for a large number of firms as it is assumed here, this is an acceptable approximation.

From equation (17), defining the maximum marginal cost required to export profitably, it comes:

$$
\varphi \alpha M_{c} P_{c}^{\sigma-1}=(1+t)^{\sigma} K_{\exp } \beta_{\bar{c}, \exp }^{*}{ }^{\sigma-1}
$$

This expression enables equation (18), expressing the zero-expected-profit condition for potential entrants, to be written in the following way (using also the expression of $\beta_{\text {aut }}$ in (20)):

$$
K\left[\frac{(1+t)^{\sigma} K_{\exp }}{K}\left(\frac{\beta_{\bar{c}, \exp }^{*}}{\phi_{c} \beta_{\text {aut }}}\right)^{\sigma-1}-1\right]+K_{\exp } \int_{\beta_{c, \text { inf }}}^{\beta_{c \exp }^{*}}\left[\left(\frac{\beta_{c, \exp }^{*}}{\beta}\right)^{\sigma-1}-1\right] f_{c}(\beta) d \beta=0
$$

This implies that

$$
\left(\frac{\beta_{\bar{c}, \text { exp }}^{*}}{\phi_{c}}\right)^{\sigma-1}=J\left[\left(\frac{\beta_{c, \text { exp }}^{*}}{\phi_{c}}\right)^{\sigma-1}\right]
$$

Where the function $J$ associates to every positive, real $x:^{12}$

$$
J(x)=\frac{\beta_{a u t}^{\sigma-1}}{(1+t)^{\sigma}}\left[\frac{K}{K_{\exp }}+\frac{1}{2 \delta(\sigma-2)}\left[x^{1 /(\sigma-1)}-(1-\delta)^{2-\sigma} x+(\sigma-2)\left(x^{1 /(\sigma-1)}-(1-\delta)\right)\right]\right]
$$

Its derivative is:

\footnotetext{
${ }^{12}$ For the sake of simplicity, we assume here that $\sigma \neq 2$.
} 


$$
J^{\prime}(x)=\frac{\beta_{\text {aut }}^{\sigma-1}}{(1+t)^{\sigma}} \frac{1}{2 \delta(\sigma-2)}\left[x^{(2-\sigma) /(\sigma-1)}-(1-\delta)^{2-\sigma}\right]
$$

It is then straightforward to show that

$$
\forall x \in\left\lfloor(1-\delta)^{\sigma-1} ;(1+\delta)^{\sigma-1}\right\rfloor,-1 \leq J^{\prime}(x) \leq 0
$$

In addition, $J\left((1-\delta)^{\sigma-1}\right)=\frac{K}{(1+t)^{\sigma} K_{\exp }} \beta_{\text {aut }}{ }^{\sigma-1}$ (note that, as trade costs are not prohibitive, this implies that $\left.J\left((1-\delta)^{\sigma-1}\right)>(1-\delta)^{\sigma-1}\right)$.

As, necessarily, $\left(\frac{\beta_{c, \exp }^{*}}{\phi_{c}}\right)^{\sigma-1} \in\left[(1-\delta)^{\sigma-1} ;(1+\delta)^{\sigma-1}\right]$, then equation (A.5) implies that $\left(\frac{\beta_{\bar{c} \text { exp }}^{*}}{\phi_{c}}\right)^{\sigma-1}<J\left((1-\delta)^{\sigma-1}\right)$.

On the other hand, from equation (16) for country $c$ and (17) for country $\bar{c}$, it comes:

$$
\left(\frac{\beta_{\bar{c}, \exp }^{*}}{\phi_{c}}\right)^{\sigma-1}=\frac{(1+t)^{\sigma} K_{\exp }}{K}\left(\frac{\beta_{c}^{*}}{\phi_{c}}\right)^{\sigma-1} \geq(1-\delta)^{\sigma-1}
$$

As a consequence, $\left(\frac{\beta_{c, \exp }^{*}}{\phi_{\bar{c}}}\right)^{\sigma-1} \in\left[(1-\delta)^{\sigma-1} ;(1+\delta)^{\sigma-1}\right], \forall c=A, B$.

Now, given (A.8), $(J \circ J)^{\prime}=J^{\prime} \circ J \times J^{\prime}$ implies that:

$(\mathrm{A} .10)\left(J \circ J^{\prime}\right)\left(\left(\frac{\beta_{c, \text { exp }}^{*}}{\phi_{c}}\right)^{\sigma-1}\right)=J^{\prime}\left(\left(\frac{\beta_{c, \text { exp }}^{*}}{\phi_{\bar{c}}}\right)^{\sigma-1}\right) \times J^{\prime}\left(\left(\frac{\beta_{c, \exp }^{*}}{\phi_{c}}\right)^{\sigma-1}\right) \in[0 ; 1], \forall c=A, B$.

As $J$ is continuous and decreasing over the interval $\left\lfloor(1-\delta)^{\sigma-1} ;(1+\delta)^{\sigma-1}\right\rfloor$, the function

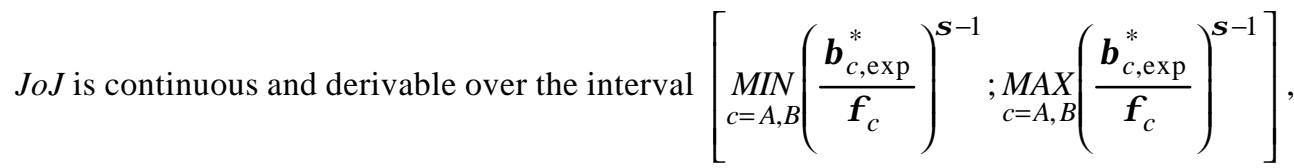
and: 


$$
\forall x \in\left[\underset{c=A, B}{\operatorname{MIN}}\left(\frac{\beta_{c, \exp }^{*}}{\phi_{c}}\right)^{\sigma-1} \underset{c=A, B}{\operatorname{MAX}}\left(\frac{\beta_{c, \exp }^{*}}{\phi_{c}}\right)^{\sigma-1}\right], 0 \leq(J \circ J)^{\prime}(x) \leq 1
$$

Now, assuming that B is the least efficient country (i.e. $\left.\phi_{\mathrm{A}} \leq \phi_{\mathrm{B}}\right)$, (A.5) implies that

$$
\left\{\begin{array}{l}
\left(\frac{\beta_{A, \exp }^{*}}{\phi_{A}}\right)^{\sigma-1}=\frac{\phi_{B}}{\phi_{A}} J\left(\frac{\phi_{A}}{\phi_{B}}\left(\frac{\beta_{A, \exp }^{*}}{\phi_{A}}\right)^{\sigma-1}\right) \geq(J \circ J)\left(\left(\frac{\beta_{A, \exp }^{*}}{\phi_{A}}\right)^{\sigma-1}\right) \\
\left(\frac{\beta_{B, \exp }^{*}}{\phi_{B}}\right)^{\sigma-1}=\frac{\phi_{A}}{\phi_{B}} J\left(\frac{\phi_{B}}{\phi_{A}}\left(\frac{\beta_{B, \exp }^{*}}{\phi_{B}}\right)^{\sigma-1}\right) \leq(J \circ J)\left(\left(\frac{\beta_{B, \exp }^{*}}{\phi_{B}}\right)^{\sigma-1}\right)
\end{array}\right.
$$

Therefore:

$$
\left.(J \circ J)\left(\left(\frac{\beta_{B, \exp }^{*}}{\phi_{B}}\right)^{\sigma-1}\right)-(J \circ J)\left(\frac{\beta_{A, \exp }^{*}}{\phi_{A}}\right)^{\sigma-1}\right) \geq\left(\frac{\beta_{B, \exp }^{*}}{\phi_{B}}\right)^{\sigma-1}-\left(\frac{\beta_{A, \exp }^{*}}{\phi_{A}}\right)^{\sigma-1}
$$

Given (A.11), this implies that, necessarily, $\left(\frac{\beta_{B, \exp }^{*}}{\phi_{B}}\right) \leq\left(\frac{\beta_{A, \exp }^{*}}{\phi_{A}}\right)$. This means that the probability for a new entrant to export is superior in the most efficient country.

The first equality in (A.9) then implies that $\left(\frac{\beta_{A}^{*}}{\phi_{A}}\right) \leq\left(\frac{\beta_{B}^{*}}{\phi_{B}}\right)$ : the probability to survive for a new entrant is inferior in the most efficient country. Or, in other words, the minimum required efficiency has more increased, compared to autarky, in the most efficient country than in the least efficient country. This proves the announced property. 


\section{LIST OF WORKING PAPERS RELEASED BY CEPII ${ }^{13}$}

\section{0}

"Syndrome, miracle, modèle polder et autres spécificités néerlandaises: quels enseignements pour l'emploi en France? ", S. Jean, working paper $n^{\circ} 00-12$, July.

"FDI and the Opening Up of China’s Economy, F. Lemoine, working paper $n^{\circ} 00-11$, June.

"Big and Small Currencies : The Regional Connection", A. Bénassy-Quéré and B. Coeuré, working paper $n^{\circ} 00-10$, June.

"Structural Changes in Asia and Growth Prospects After the Crisis", J.C. Berthélemy and S. Chauvin, working paper $n^{\circ} 00-09$, June.

"The International Monetary Fund and the International Financial Architecture", M Aglietta, working paper $n^{\circ} 00-08$, May.

"The Effect of International Trade on Labour-Demand Elasticities : Intersectoral Matters", S. Jean, working paper $n^{\circ} 00-07$, May

"Foreign Direct Investment and the Prospects for Tax Co-Ordination in Europe", working paper $n^{\circ}$ 00-06, April.

"Forum Economique Franco-Allemand Deutsch-Französisches Wirtschaftspolitisches Forum, Economic Growth in Europe: Entering a New Area? The First Year of EMU, $6^{\text {th }}$ meeting, Paris, January 17-18, 2000", working paper $n^{\circ}$ 00-05, April.

"The Expectations of Hong Kong Dollar Devaluation and their Determinants", B. Rzepkowski, working paper $n^{\circ}$ 00-04, February.

"What Drove Relative Wages in France? Structural Decomposition Analysis in a General Equilibrium Framework, 1970-1992", S. Jean and O. Bontout, working paper $n^{\circ}$ 00-03, January.

"Le passage des retraites de la répartition à la capitalisation obligatoire : des simulations à l'aide d'une maquette", O. Rouguet and P. Villa, working paper $n^{\circ}$ 00-02, January.

"Rapport d'activité 1999", working paper n00-01, January.

\footnotetext{
${ }^{13}$ Working papers are circulated free of charge as far as stocks are available; thank you to send your request to CEPII, Sylvie Hurion, 9 rue Georges Pitard, 75015 Paris, or by fax (33) 0153685504 or by e-mail Hurion@ @epii.fr. CEPII is also on the Web : http://www.cepii.fr.
} 
"Exchange Rate Strategies in the Competition for Attracting FDI", A. Bénassy-Quéré, L. Fontagné and A. Lahrèche-Révil, working paper $n^{\circ}$ 99-16, December.

"Groupe d'échanges et de réflexion sur la Caspienne. Recueil des comptes-rendus de réunion (déc. 97-oct. 98)", D. Pianelli and G. Sokoloff, working paper $n^{\circ}$ 99-15, November.

"The Impact of Foreign Exchange Interventions: New Evidence from FIGARCH Estimations", M.Beine, A. Bénassy-Quéré and C. Lecourt, working paper $n^{\circ}$ 99-14, September.

"Forum Economique Franco-Allemand Deutsch-Französisches Wirtschaftspolitisches Forum", Reduction of Working Time/Eastward Enlargment of the European Union, 5 meeting, Paris, July 6-7 1999", working paper $n^{\circ}$ 99-13, September.

"A Lender of Last Resort for Europe", M. Aglietta, working paper $n^{\circ}$ 99-12, September. OUT-OF-PRINT

"La diversité des marchés du travail en Europe : Quelles conséquences pour l'Union Monétaire ; Deuxième partie : Les implications macro-économiques de la diversité des marchés du travail", L. Cadiou, S. Guichard and M. Maurel, working paper $n^{\circ}$ 99-11, June.

"La diversité des marchés du travail en Europe : Quelles conséquences pour l’Union Monétaire ; Première partie : La diversité des marchés du travail dans les pays de l'Union Européenne", L. Cadiou and S. Guichard, working paper $n^{\circ}$ 99-10, June.

"The Role of External Variables in the Chinese Economy; Simulations from a macroeconometric model of China", S. Dees, working paper $n^{\circ}$ 99-09, June.

"Haute technologie et échelles de qualité : de fortes asymétries en Europe", L. Fontagné, M. Freudenberg and D. Ünal-Kesenci, working paper $n{ }^{\circ} 99-08$, June.

"The Role of Capital Accumultion, Adjustment and Structural Change for Economic TakeOff: Empirical Evidence from African Growth Episodes", J.C. Berthélemy and L. Söderling, working paper $n^{\circ}$ 99-07, April.

"Enterprise Adjustment and the Role of Bank Credit in Russia: Evidence from a 420 Firm's Qualitative Survey", S. Brana, M. Maurel and J. Sgard, working paper $n^{\circ}$ 99-06, April.

"Central and Eastern European Countries in the International Division of Labour in Europe", M. Freudenberg and F. Lemoine, working paper $n^{\circ}$ 99-05, April.

"Forum Economique Franco-Allemand - Economic Policy Coordination $-4^{\text {th }}$ meeting, Bonn, January 11-12 1999", working paper $n^{\circ}$ 99-04, April. 
"Models of Exchange Rate Expectations : Heterogeneous Evidence From Panel Data", A. Bénassy-Quéré, S. Larribeau and R. MacDonald, working paper $n^{\circ}$ 99-03, April.

"Forum Economique Franco-Allemand -Labour Market \& Tax Policy in the EMU", working paper $n^{\circ}$ 99-02, March.

"Programme de travail 1999", working paper $n^{\circ}$ 99-01, January.

\section{8}

"Rapport d'activité 1998", working paper n98-15, December.

"Monetary Policy under a Fixed Exchange Rate Regime, The Case of France 1987-1996", B. Mojon, working paper $n^{\circ} 98-14$, December.

"Wages and Unemployment: Trade-off Under Different Labour Market Paradigms", O. Bontout and S. Jean, working paper $n^{\circ} 98-13$, November.

"Structures financières et transmission de la politique monétaire, analyses comparatives de l'Allemagne, la France, l'Italie et le Royaume-Uni", B. Mojon, working paper $n^{\circ}$ 98-12, October.

"Le marché du travail britannique vu de France", M. Fouquin, S. Jean and A. Sztulman, working paper $n^{\circ} 98-11$, October.

"Compétitivité et régime de change en Europe Centrale", M.Aglietta, C. Baulant and V. Coudert, working paper $n^{\circ} 98-10$, October.

"Sensibilité des salaires relatifs aux chocs exogènes de commerce international et de progrès technique : une évaluation d'équilibre général", S. Jean and O. Bontout, working paper $n^{\circ}$ 98-09, September.

"Evolution sur longue période de l'intensité énergétique", P. Villa, working paper $n^{\circ}$ 98-08, August.

"Sacrifice Ratios in Europe : a Comparison", L. Boone, B. Mojon, working paper $n^{\circ}$ 98-07, August.

"La politique monétaire et la crise japonaise", S. Guichard, working paper $n^{\circ}$ 98-06, July.

"La régionalisation du commerce international : une évaluation par les intensités relatives bilatérales", M. Freudenberg, G. Gaulier, D. Ünal-Kesenci, working paper $n^{\circ}$ 98-05, July.

"Pegging the CEEC's Currencies to the Euro", A. Bénassy-Quéré, A. Lahrèche-Révil, working paper $n^{\circ} 98-04$, July. 
"The International Role of Euro", A. Bénassy-Quéré, B. Mojon, A.D. Schor, working paper $n^{\circ}$ 98-03, July.

"EMU and Transatlantic Exchange Rate Stability", A.Bénassy-Quéré and B. Mojon, working paper $n^{\circ}$ 98-02, April.

"Programme de travail 1998", J.C. Berthélemy, working paper n 98-01, April.

"Why the euro will be strong: an approach based on equilibrium exchange rates", M. Aglietta, C. Baulant and V. Coudert, working paper $n^{\circ}$ 97.18, December.

"How Foreign Direct Investment Affects International Trade and Competitiveness ; an Empirical Assessment", L. Fontagné and M. Pajot, working paper $n^{\circ}$ 97-17, December.

"Cycles de poduction industrielle : une analyse historique dans le domaine des fréquences", P. Villa, working paper $n^{\circ} 97-16$, November.

"Internal and External Policy Coordination : a Dynamic Analysis", F. Capoën and P. Villa, working paper $n^{\circ} 97-15$, November.

"Optimal Pegs for Asian Currencies", A. Bénassy-Quéré, working paper $n^{\circ}$ 97-14, October. OUT-OF-PRINT

"Pour ou contre le système commun de TVA ? ", C. Lefebvre, working paper $n^{\circ}$ 97-13, June.

"The Euro and Exchange Rate Stability", A. Bénassy-Quéré, B. Mojon and J. Pisani-Ferry, working paper $n^{\circ} 97-12$, June.

"Estimation du cycle à l'aide d'un modèle à tendance stochastique and application au cas du Royaume-Uni", L. Boone, working paper $n^{\circ}$ 97-11, June.

"Looking for French Monetary Policy", B. Mojon, working paper $n^{\circ}$ 97-10, June. OUT-OFPRINT

"Incertitude sur le choix du modèle et rationalité", P. Villa, working paper $n^{\circ}$ 97-09, May.

"Quel est l'impact du commerce extérieur sur la productivité et l'emploi ? ", O. Cortes and S. Jean, working paper $n^{\circ}$ 97-08, April.

"Trade Patterns Inside The single Market", L. Fontagné, M. Freudenberg and N. Péridy, working paper $n^{\circ}$ 97-07, April.

"The Exchange Rate Policy of the Euro: A Matter of Size", P. Martin, working paper $n^{\circ} 97$ 06, April. OUT-OF-PRINT 
"Ces taux de de change réels qui bifurquent", P. Villa, working paper $n^{\circ}$ 97-05, April.

"Chômage non-qualifié et imitation : les raisons d'un accord international sur la propriété intellectuelle", L. Fontagné and J.L. Guérin, working paper n 97-04, March.

"Symmetry and Assymmetry of Supply and Demand Shocks in the European Union: a Dynamic Analysis", L. Boone, working paper $n^{\circ}$ 97-03, February. OUT-OF-PRINT 